case of the alpha-beta-globulin, this basic character is inconsistent with a hypothesis that this new fraction results from a complex of globulins with either heparin or with fatty acid released during the clearing of lipæmia. Herbst and Hurley ${ }^{5}$ made similar observa. tions and argued against protein-heparin complexes by pointing out the unusually high lipid/protein ratio in the lipo-pre-albumin. Lipo-pre-albumin also appears after intravenous administration of $\mathrm{fat}^{\mathrm{B}}$.

The mechanisms which cause diminution of zeroand beta-2-lipoproteins during the clearing reaction appear to be well understood, and the overall increase in mobility of beta-1-lipoprotein and lipo-albumin can be explained. T'he significance of the three new protein bands is more obscure. Two are metachromatic, yet other evidence is against their being a protein-heparin complex. This is less surprising when considered with our inability as yet to identify the pre-formed metachromatogens of normal sera with any known substance. One of the new bands, lipopre-albumin, has a high lipid/protein ratio, whereas another of the new bands, gamma-1-globulin, is apparently free of lipid. The rapidity of these changes in the pattern of serum protein after intravenous heparin imquestionably makes direct interaction \& superficially attractive hypothesis, yet all available evidence seems to be against it. One can only conclude that a number of the changes listed above are due to mechanisms which are unknown at present

'These studies, carried ont at U.S. Army Hospital, Fort Riley, Jansas, were assisted by a grant-in-aid from the Wolfom--Meyer Charity Foundation, Miami, Florida, U.S.A. We also are grateful for important help given by officers of the 18th Infantry Regiment and by Dr. J3. E. Clegg and others of the staff of the Departiment of Chemistry, Kansas State College. WJLLIAM QUTTMAN Wolfson BRENTON H. P'ENWARDTE, JUN.

130 Waverly,

Highland Park 3 ,

Michigan.

Dee. 13.

${ }^{1}$ Wolfson, W. Q., Proc. 3rd Interim Session, Amer. Rhemnat. Assoc. (in the press).

2 Bergström, S., and 13örgstrom, 13., "Ann. Rev. Biochem.", 25, 177 $(1956)$.

'Gordon, R. S., J. Clin. Invest., 34, 477 (1955).

"Wolfson, W. Q., and J'enwarden, jın., R. II., Clin. Res. Proc., 4, 254 (1956)

${ }^{5}$ Uerbst, F. S. M., and ILurley, N. A., J. Clin. Invest., 33, 907 (1954)

"Herbst, F. S. M., lever, W. F., and Wakddell, W. R., Science, 123, $843(1956)$

\section{Thyroid Adenomas in Sheep administered Iodine-13I Daily}

THE role of iodine-131 in the possible development of thyroid tumours has been a matter of considerable concern in view of its widespread clinical use. The occurrence of thyroid tumours in rats after single-dose administration of iodine-131 has been described by Goldberg and Chaikoff ${ }^{1}$; but no reports of such tumour devolopment in other species have been recorded. During the course of an extended investigation of the effects of iodine-131 administered daily to sheep ${ }^{2,3}$, thyroid adenomas were encountered in four of a group of five sheep which were exposed to $5 \mu$ c. iodine-131 per day for their lifetime. The development of a fibrosarcoma in the thyroid region of the remaining member of this group is reported separately ${ }^{4}$.
The principal phase of the extended experiment initiated in 1950 has involved the daily oral administration of carrier-free iodine-131 at levels ranging from 0.005 to $1,800 \mu \mathrm{c}$. to Suffolk sheep. Offspring were exposed to iodine-131 in foetal life and by way of the milk during the suckling period. When ewe lambs reached the weaning age of four months, representative numbers were placed on the same iodine-131 regimen as their dams. The sheep were maintained on a diet low in stable iodine in order to ensure maximum uptake of iodine-131. Weekly external monitoring of the thyroids of all sheep was performed throughout the experiment.

The estimated dose to the thyroid gland of a representative animal showing tumour involvement was 30,000 rads for the entire five and a half years of life. The dosage calculations, however, are considered only crude estimates, since, during the lifetime of the animals, the thyroid exhibits growth, seasonal changes in weight ${ }^{5}$, and then a reduction in size due to radiation damage.

Among the animals showing tumour involvement, two had adenomas which were detected histologically but were not observed grossly at necropsy. In the other two animals the tumours appeared as small, raised lesions. The gland of one animal presented a single tumour that did not exceed $1 \mathrm{~cm}$. in greatest diameter, and in the other ewe the involved lobe had three small tumours, none of which exceeded $4 \mathrm{~mm}$. in greatest diameter.

Neither the six ewes of the same age which were exposed to $0.15 \mu \mathrm{c}$. per day for their life-time nor any of the twenty-five aged control animals showed any evidence of thyroid tumours. The dams of the affected animals were administered 5 u.c. daily from two years of age until they were killed three to four years later, but showed no tumour development. 'The thyroid glands of sheep fed 15-1,800 uc. per day also contained no tumours. However, these groups were fed iodine-131 for significantly shorter periods, were killed at an earlier age, and frequently exhibited severe thyroid damage or ablation, thus limiting the basis for comparison with the group under consideration in this report.

This paper is based on work performed under Contract $W-31-109-E n g-52$ for the Atomic Inergy Commission.

'The technical assistance of N. L. Dockum, J. Jane Coleman and Glenda Vogt for photomicrographs and histological preparations, and of M. IA. Kerr and animal farm staff for care of animals is gratefully acknowledged.
L. K. BUSTAD
S. Marks
L. A. George, JUN.*
L. J. Setanitur

Biology Operation,

Hanford Laboratories,

General Electric Co.,

Richland, Washington.

$$
\text { Jan. } 5 .
$$

* Present address: School of Medicine, University of Washington, Seattle, Washington.

1 Goldberg, R. C., and Chaikoff, I. L., Arch. Path., 53, 22 (1952).

${ }^{2}$ Bustad, L. K., George, jun., L. A., Marks, S., Warner, D. L., Barnes, C. M., Herde, K. E., and Kornberg, H. A., Radiation Res. (in the press).

${ }^{2}$ Marks, S., Dockum, N. L., and Bustad, L. K., Amer. J. Path. (in the press).

- Marks, S., George, jun., L. A., and Bustad, L. K., Cancer (in the press).

- Seidell, A., and Fenger, F., J. Biol. Chem., 13, 517 (1913). 